\title{
The Silence of the Archives: \\ Business History, Postcolonialism and Archival Ethnography
}

\author{
Stephanie Decker ${ }^{1}$
}

\begin{abstract}
History as a discipline has been accused of being a-theoretical. Business historians working at business schools, however, need to better explicate their historical methodology, not theory, in order to communicate the value of archival research to social scientists, and to train future doctoral students outside history departments. This paper seeks to outline an important aspect of historical methodology, which is data collection from archives. In this area, postcolonialism and archival ethnography have made significant methodological contributions not just for non-Western history, as it has emphasized the importance of considering how archives were created, and how one can legitimately use them despite their limitations. I argue that these approaches offer new insights into the particularities of researching business archives.
\end{abstract}

Keywords: historical methodology - postcolonialism - archival ethnography corporate archives - business history - Africa

\footnotetext{
${ }^{1}$ Aston Business School, Aston Triangle, Birmingham B4 7ET, s.decker@aston.ac.uk.

Acknowledgements: I would like to thank Mick Rowlinson, Bill Cooke, Andrew Popp, Stefanie van de Kerkhof, Ulrike Lindner, Bernardo Batiz-Lazo and Giovanni Favero for their individual feedback, as well as colleagues who commented on the paper at workshops and presentations at Coventry University, Mannheim University, the Business History Unit at the London School of Economics, and Lancaster University Management School. Sarah Kinsey, archivist at the HSBC, provided valuable guidance on the theoretical basis of contemporary archival practices. Lastly, I am grateful to my former doctoral supervisors, Rory Miller and Dmitri van den Bersselaar, whose thorough training has stood me in good stead.
} 


\section{Introduction}

"Philosophy of science is about as useful to scientists as ornithology is to birds."

Richard P Feynman

This glib comment by the Nobel-prize winning physicist Richard Feynman seems to encapsulate the attitude of many historians towards theory and methodology. Beverly Southgate similarly highlighted this pervasive attitude in his book on historiography: "The philosophy of history has for the most part been safely cordoned off as a sub-branch of philosophy, with which historians need not be greatly concerned - any more than most scientists are concerned with the philosophy of science, or practising artists with theories of aesthetics." As a result of this attitude, however, some of the significant skills practicing historians develop as members of a craft-based disciplines - which has been accused of being one of the least self-reflective and most theory-averse of them all (Duara, 1998) - remain tacit and unacknowledged outside the discipline.

For business history, this is a fundamental problem. In the last decade, business historians in the UK changed their institutional location from history departments to business and management schools. ${ }^{2}$ David Cannadine's What is History Now? (2002), for example, does not mention business and economic history. And while economic history has increasingly leaned towards cliometrics and moved into economics departments, and sometimes into business schools, business historians have always been uneasy with its economic universalism that downplayed agency (Down, 2001a), and are now in search of a disciplinary identity in their new institutional home of the business school (Amatori \& Jones, 2003, p. 5; Kobrak \& Schneider, 2011, p. 403). Especially for more junior scholars this means greater engagement with social scientists, and publishing historical work in social science journals. Considering the generally high hurdles that qualitative scholars encounter when trying to publish in major journals (Birkinshaw, 2004), this is a significant problem. Moreover, it raises the issue of how doctoral students can be trained in historical approaches if they are no longer part of history departments.

All of these challenges have highlighted the need to explain the methods of business history in relation to business and management studies. As a small subject, business history needs to make connections with other fields in order to be able to join the larger 'conversations'. Hence business history as a field is looking for new intellectual avenues to make contributions in this new institutional setting that go beyond providing data and continue the integrity of a historical research agenda (Jones \& Khanna, 2006). This is now discussed

\footnotetext{
${ }^{2}$ See for example the leading journal Business History which was founded by the Department for Economic and Social History at the University of Liverpool. Today the department does not exist anymore, and the main editorial roles are held by scholars based in Management Schools. (J. Wilson \& Toms, 2008)
} 
frequently in the major business history journals, see for example Eric Godelier's challenge in Enterprise \& Society and the responses from other business historians (Godelier, 2009a, 2009b; Kobrak, 2009; Popp, 2009; Tiffany, 2009), work on the impact and citation of business history papers (Eloranta, Ojala, \& Valtonen, 2008; Eloranta, Valtonen, \& Ojala, 2010), and by organizational studies scholars with an interest in business history such as Mick Rowlinson (Clark \& Rowlinson, 2004; Michael Rowlinson \& Delahaye, 2009).

When it comes to epistemology and methodology, I personally think that business historians need to return to their disciplinary origins in history, regardless of where they are based institutionally (Kobrak \& Schneider, 2011; Popp, 2009). Moreover, I do not think that this will limit our ability to relate to research agendas in the social sciences; on the contrary, I believe it will enable us to make clearer contributions, even if this may mean to adopt the terminology of research approaches such as case method, which is often close to what historians do. In the multi-disciplinary environment of business schools, identification and collaboration is based on one's methodology. Hence debates about history being a-theoretical are misplaced in my view, because the real issue is that historians are not explaining their metholodogy, and in fact are missing a language and a format to do so that is compatible with the approach in social sciences.

In this paper I argue that history as a discipline has a methodology of reconstruction from archival material. After a brief overview of how historians have discussed their archival research strategies, I focus on the impact that postcolonialism had on historical practices of archival research, before discussing archival research techniques that are specifically relevant to contemporary organizational archives. Historical research influenced by postcolonial theory has developed an ethnographic approach to colonial administrative archives that focuses on the silencing that occurs as records are created. The focus here is that of archives as a tool for colonial rule (Breckenridge, 2012; Cohn \& Dirks, 1988; Dirks, 2002). Although some have taken these ethnographic approaches further (Mills \& Helms Mills, 2011; Stoler, 2009), they are not suitable for all organizational archives, which often suffered from significant neglect and were usually less central to management and control practices than those created by state bureaucracies.

Thus business records can suffer from different kinds of silences, created by other processes. Finally I suggest research strategies when archival material is overabundant, which is often the case for contemporary sources. This in effect leads to selective silencing by the researcher, and although in many archives this is difficult to do in a methodical manner due to the nature of the collections themselves, historians ought to be more explicit about what their practice is in such situations. 


\section{In conversation with archives: on voice, silence and postcolonialism}

Despite Dominick LaCapra's accusation of historians' archival fetishism (cited in Zammito, 1993), there are few treatments of archival work by historians or historical scholars as such. At the British Academy of Management Annual Conference in 2011, a workshop on business archives attracted quite a few nonhistorians, but the problem of not having a language for the methodology of archival work seemed to make it difficult to communicate. ${ }^{3}$ While historians talked about how to identify an archive and negotiate access, social scientists wanted to hear of what to do once they were in one.

Methodological treatments of archival work are especially rare, but historians do discuss their data and data collection, usually when they pose problems such as scarcity or over-abundance, or both. In business history this actually has some tradition, see for example the preface to Charles Wilson's corporate history of Unilever (C. Wilson, 1954) or Coleman's (1987) discussion of the tension inherent in doing historical work on essentially private corporate archives. Here I want to focus on more recent papers, because the focus of business history on corporate archives is no longer considered a given. Of this limited material, I want to focus on three pieces in particular, as I think they represent different approaches: Mills \& Helm Mills (2011) approach archives from the perspective of organization studies, Newton and Carnevali (2010) are business historians, and Miescher's work (2009) falls in the area of African Studies.

Interestingly, the only ones who define the term 'archive' are Mills \& Helm Mills (2011), and they differentiate between a pragmatic and a Foucauldian definition. Firstly archives are materials specifically collected for the purpose of preserving a history and housed in a distinct location. They differentiate this from the poststructuralist definition of an archive as a complex system of embedded rules that determines the production of knowledge. This notion of knowledge production has been influential for research in African history, see for example Cooper and Packard (1997) and van den Bersselaar (2004).

Yet the nature of archival collections in formerly colonised countries are actually somewhat at odds with the postcolonial understanding of how archives are created. The colonial archives and literary expressions that Gayatri Chakravorty Spivak and Edward Said read against the grain create silences by (conscious and unconscious) manipulation of information, because archives are a technique of colonial rule. Archives in Africa and other less developed countries, however, suffer from autocratic suppression of information, complete lack of transparency and accountability - basically the absence of a functioning bureaucratic system. This leaves a problematic legacy for the writing of future history (Austin, 2012, p. 9; Breckenridge, 2012, p. 1; Ellis, 2002, p. 12). Thus approaches such as reading archives against, or indeed along the archival grain, as advocated by Ann Laura

\footnotetext{
${ }^{3}$ There are also "Meet the Archivist" workshops by the Business Archives Council, see: (Business Archives Council, 2011)
} 
Stoler (2011), become almost impossible to implement as a result of the dearth of existing deposits.

Interestingly, for business historians, this is also a common condition, as business records are often kept in a very patchy manner, and ethnographic approaches such as Stoler's can be difficult to implement. In general, archives which allow the researcher to reconstruct the embedded rules of knowledge production are quite rare for business historians. Archives with a different genesis than those almost exemplary types described by Mills \& Helm Mills (2011) abound, and these are subject to a much wider range of data collection practices than their Foucauldian archive concept allows for. This complicates the nature of "silences" further, because business records, like many public records in Africa, do not actually get deposited into archives, because firstly there is no interest in history, and secondly there is a lack of accountability.

Probably the best treatment of the extent and diversity of silences that occur in history is Michel-Rolph Trouillot's (1995, p. 26) Silencing the Past, in which he creates a comprehensive categorisation of where silences enter historical production:

1. Fact creation, or the making of sources

2. Fact assembly, or the making of archives

3. Fact retrieval, or the making of narratives

4. Retrospective significance (Nachgeschichte), or the making of history

I would suggest that the making of narratives still breaks down further into data collection, analysis, and mode of reporting, and the last two of these, analysis and reporting, engages with the historiography and thus already determines how it wants to contribute to the making of history (even though this is only intentional or indeed aspirational). This paper discusses predominantly the making of archives, as well as the making of sources, and eventually looks at data collection strategies. While the latter appears to be part of fact retrieval, it is in many ways also a form of archive creation by the research. Hence although his categorisation is elegantly succinct, in practice this is not a realistic description of the making of any individual narrative, as Trouillot himself readily admits (Trouillot, 1995, p. 27).

A good example of the opposite type of corporate archive, which are considerably more hap-hazard in their creation, is given by Newton and Carnevali (2010), who describe the nature of evidence for their research on the history of the manufacturing and trade of pianos in the nineteenth century. Here many historical sources have been lost, are widely dispersed, hard to identify and sometimes not accessible. This is similarly the reality for much research in African Studies (Miescher, 2009). Interestingly, and in contrast to Mills and Helm Mills, Newton and Carnevali do not describe their assumptions and research strategies of archival material, which form the basis of their analysis. On the other hand, however, they are well aware that archival remains are not always the product of conscious knowledge production and collection, but result from a haphazard process of disinterest, forgetting, and the loss of organizational 
identity as firms close down. Mills \& Helm Mills, however, are only interested in the more willful forms of silencing, as they specifically selected (with some difficulty) large and comparable archives. They show only limited awareness that they are working within a very special type of archive, which does not reflect the breadth and diversity of archival work undertaken by historians.

An interesting comparison here is Stephan Miescher's paper (2009) on his research on the Volta River Authority (VRA) in Ghana, which highlights some of the issues I will discuss subsequently with regard to the unusual find of a reasonably extensive and well-kept African archive of a parastatal organisation. He contextualizes its rarity within the context of poor survival chances of historical records in African countries, while at the same time reflecting on the postcolonial context of its production and preservation. What Miescher encountered is true for other organizational archives such as Unilever's United Africa Company archives, or the World Bank Archives (Austin, 2012, pp. 10-11), which have probably kept better records on African history than some African national archives. Yet these collections need to be approached with caution postcolonial ethnographic approaches are certainly necessary to read along and against the grain of these files, but there also needs to be an understanding that these organisations reflect bureaucratic cultures that are very different from those of colonial empires. Companies are often deeply disinterested in their own history. I argue that this is what makes research on business records all the more challenging, as one's methodology needs to encompass the breadth and diversity of silences within the material, not all of which can be attributed to the kind of silences that postcolonialism has focused on.

Silences imply that there is also voice, and most mainstream historians are familiar with the metaphor of archival voice. Richard Evans, for example, argues that "documents do have an integrity of their own, they do indeed 'speak themselves'" and elsewhere that "the past does speak through the sources, and is recoverable through them" because language and grammar are not arbitrary signifiers with no relationship to reality, as this would make any form of communication impossible. He cites EP Thompson: "the historian has got to be listening all the time ... If he listens, then the material itself will begin to speak through him." These are, however, voices in a critical conversation, as the language of documents is never transparent, and the past can only be glimpsed "through a glass, darkly" (Evans, 1999, pp. 104, 112, 116, 126).

Postcolonialism holds that these are the voices that represent control and silencing of 'others', and have to be treated at a critical distance. Ann Laura Stoler's (2009, pp. 3, 7, 73-76) approach of reading 'along the archival grain' is interesting in this regard for business historians, because she makes use of those 'voices' in a slightly different way. She describes her approach as focusing on 'non-events', by which she means occurrences that do not make it into any standard history books, precisely because they fail in their intentionality (i.e. they have no Nachgeschichte, no historical after-effects). These non-events can be transgressive, in that they - intentionally or unintentionally - challenge accepted norms and tacit knowledge, and thus reveal the cognitive models and cultural standards in an ethnographic manner. Postcolonial research has often 
focused on prison and judicial records to gain insight into social norms and their interpretations through the lens of major transgressions.

Stoler (2009, p. 106) extends this into the practices of everyday bureaucracy, which makes it particularly relevant to business history. Moreover, she moves beyond the transgressions into what she refers to as the 'subjunctive', the envisioning of alternative, non-realised, but seemingly possible futures. So her history of non-events is defined by its failure to produce historically relevant results, or Nachgeschichte, and its relevance lies precisely in identifying the ethnographic quality of the past. In many ways these ethnographic approaches are a form of 'thick contextualization': Historians always contextualize the past events they describe, but Stoler's (2009, pp. 181-185, 238, 249, 252) approach is entirely focused on reconstructing context, because that is her main research object - the events themselves are of only limited relevance. This makes a specific kind of 'dissonant source' more relevant - breaks from the norm in correspondence, for example in mostly technical and practical discussions occasionally letters and memos appear that are openly critical or unusually reflective - and Stoler advocates a less even-handed archival practice in such cases.

On this methodological level, postcolonialism's focus on how the context was conditioned has become widely accepted within the historical discipline, probably because some historians had already worked on consistent source bias and ideology, see for example the well-known argument of the 'official mind' of colonial administration Africa and the Victorians (Robinson \& Gallagher, 1961). Postcolonialism's contribution lies in having improved contextualization in history by addressing how the lack of voice of the 'victims of history' can also be heard. In contrast, in business and management studies, the influence of these approaches has been mostly confined to critical management studies international business, for example, remains quietly ethnocentric as a result of it nomothetic research orientation (Westwood, 2004).

Although Stoler seems to lean heavily towards understanding the past on its own terms, the concepts she investigated - race and gender - are decidedly contemporary. This inherent tension within history between its two polarities of history as it was in the past (based on Ranke) and History as it should be for the present and the future ('practical' or 'useful' history) has certainly been as important and as problematic in business history (Down, 2001a). Yet this dialectic tension has been fruitful for the discipline (Southgate, 1996). Leopold von Ranke challenged explicitly ideological History of the nineteenth century. Similarly, overly positivist and simplistic lower-case, factual history "as it was" has been challenged by EH Carr and subsequently by postmodernists. Thus it is unsurprising that historians like Richard Evans find it easy to integrate and value many contributions of postmodernist approaches, and that the purported "end of history" has ironically led to a productive (re-) discovery of subaltern history (Iggers, 2009), and also for a more self-conscious treatment of temporality in history (Lorenz, 2011, p. 26). Hence 'doing history' involves maintaining a careful balance between the present - the research questions, the constructs, the narrative - and a sound anchoring in the past - the evidence, the archival record, 
the oral history. Trouillot (1995) refers to this as the two sides of historicity, where socio-historical process and narrative representations of the past intertwine, neither existing independently of the other. Here practicing historians and their postmodernist critics have found some agreement:

"The past has its own 'voices' that must be respected, especially when they resist or qualify the interpretations we would like to place on them"

- Dominick La Capra, Rethinking Intellectual History, pp. 63-64, cited in Zammito (1993, p. 808).

In business history, and management and organizational history, these different positions within historical research take on a slightly different shape. Management and organizational history frequently views history as ideology, in its more sophisticated form as history as rhetoric and a management tool (Delahaye, Booth, Clark, Procter, \& Rowlinson, 2009; Suddaby, Foster, \& Trank, 2010), or less self-consciously as identity work to justify the status quo - a practice criticized by Down (2001b) and Mees and Walker (2009).

But as a practicing business historian, I find some of this seems to miss the point: the widespread, not exactly benign neglect of business archives shows a fundamental lack of interest within organisations for their own past. Most archivists struggling to maintain under-resourced collections probably wish that history was used as a management tool more often, because a 'practical history' despite its inherent dangers of shaping collections in specific ways - would certainly ensure the survival and maintenance of archival records. At a World Bank workshop devoted to its archives and its relationship with history, William Becker remarked that the archives are the memory of an organization. ${ }^{4}$ Yet the organisations themselves are often not interested in their own memories, and if they were, what they would want from them would be very different from what outside researchers would hope to find.

And although reconstructions of history from sources can never be objective, however much self-interest is curbed, this does not mean that reconstructing the past is intrinsically flawed (Lorenz, 2011, p. 26). Rather all reconstruction is inherently inter-subjective, at the very least because the past and the present are always in a conversation in order to create historical narrative. I would consider reconstruction far more important and more basic than any other approach, such as construction or deconstruction, because reconstruction is the basic methodological orientation of the discipline (Michael Rowlinson, Stager Jacques, \& Booth, 2009, p. 290). Like all reconstruction, it suffers from uneven, complex and confusing evidence, multiple explanations, the eventual choice to prioritize one account over another, the bias inherent in the intellectual framework of the researcher, and the fundamental silence of some historical sources. Southgate (1996, p. 124), for example, clarifies that the "need to avoid any pretentious claims to be able to reconstruct the past 'as it was' [...] does not imply the need for silence".

\footnotetext{
4 "Using History to Inform Development Policy: The Role of Archives", World Bank, Washington DC, 26 October 2012.
} 
Thus reconstruction clearly suffers from sometimes inexplicable absences, as well as competing meanings at its very core, in the historical sources themselves (Trouillot, 1995, p. 29). And those historians whose work is recognized for its quality, as well as those who have been sharply criticized or even hounded out of the profession (Evans, 1999), have been judged not primarily on the beauty of their narrative (even though readability is considered inherently valuable), but on the quality of their archival work. This points towards clear, if tacit, standards for data collection from archives, even though greater methodological diversity is now widely accepted within the discipline (Lorenz, 2011, p. 33).

\section{Working with postcolonial archives}

If many historical narratives are first formed in the archive where researchers engage with the voices and silences of the past, then how do historians approach their research sites? Finding and selecting archives is always influenced by their accessibility, which is a particular issue for business historians relying on private corporate archives (Coleman, 1987), as well as for historians of Africa, where archival records are even more difficult to find and access. I will begin by briefly describing the common problems for these archives before addressing the wider issue of archival silences.

\subsection{Archives for business history: metropolitan and postcolonial}

Business historians usually draw on corporate archives, which may be held privately by a company or deposited at a public archive where access is usually less problematic. They tend to embargo the last 20 to 30 years of records, similar to public archives, though material relating to personal information can be embargoed longer or may be removed. This does not affect published or public documents, such as certain reports or the annual statements. As these collections are, however, private, corporate archives are not technically bound to these timescales, so practices are not at all uniform or predictable.

Generally speaking, the records of privately held companies tend to be more problematic than those of publicly held corporations: it is less likely to contain any obvious series of records (board meeting minutes, etc.), less material is generally collected because reporting requirements are limited, there is rarely a consistent policy of record keeping, and access can be harder to negotiate if still held by the company. When deposited, these records are more markedly uneven in coverage, and allow fewer assumptions about the structure and organization of the firm.

The most comprehensive corporate record collections tend to belong to large public firms with a long history, especially those that had corporate histories written, whether of the public relations or the academic type. When companies of this kind fail, it can be difficult to preserve these files, because collections tend to be very large. They can be taken up by public or university libraries that have manuscripts collections. Examples for this abound: the Guildhall Library in 
London, the Bodleian Library and its affiliated libraries at Oxford University, some college-based libraries at Cambridge University (such as Churchill College), the Bancroft Library at Berkeley University, the Baker Library at Harvard Business School, or the recent acquisition of the WHSmith archive by the University of Reading (2011).

Some of the largest and richest corporate archives are owned and managed by the firms themselves, and in the case of multinationals may have deposits made by their subsidiaries (though these may not be complete). Worth mentioning here, though in no way an exhaustive list, are Unilever, BP, HSBC, and Barclays. These deposits can be identified through the National Archive's "Access to Archives" (A2A) website. ${ }^{5}$ Accessing and using these private files usually requires negotiating access and requesting permission to publish, sometimes on an ad hoc basis. Many corporate archivists have included some oral history resources, and are also willing to contact former employees through retirees' associations to arrange interviews.

So while often hard to identify and occasionally tricky to access, generally the coverage and organisation of metropolitan business archives is, though decentralised, relatively good, and can be augmented by using public governmental files such as the National Archives. Important here is that multinational firms sometimes hold significant resources on postcolonial history.

Archives in postcolonial countries, by contrast, have either been destroyed, or are in the process of being destroyed by neglect. In addition to this they are usually inaccessible, and frequently contain only hap-hazardly collected fragments of information (Austin, 2012, pp. 9-10). In between there are true gems of well-preserved and consistently collected records, but continuous series of files usually cease with the colonial period. ${ }^{6}$ Public archives suffer from the failure of ministries to deposit materials, which does not allow business history researchers to augment material from the public side. The historian Stephan Miescher encountered the current record keeping practice of the Ghanaian government, a country that generally has a reasonably efficient archival service by African standards, on a visit to Osu Castle, the seat of government:

"Finally, we were led into the former slave dungeons just above the roaring surf. Since the electricity no longer worked, we carefully stumbled from one room to the other. The dungeons were not empty. We noticed shelves stacked with files along the walls and slowly realized that the floor was covered with paper as well. When the surf had splashed into the dungeons, as our guide explained, the guards had thrown the old files

\footnotetext{
${ }^{5}$ (The National Archives (UK), 2011)

${ }^{6}$ In addition to the VRA archives that will be discussed further in this paper, Ghana also has a national archive, the Public Records and Archives

Administration Department (PRAAD), which holds comprehensive file series of colonial records as well as the reasonably new acquisition of the papers of the first independent head of state, and arguable founder of modern Ghana, Kwame Nkrumah.
} 
onto the ground to mop up the water. Curious about what the material might entail, one of us picked up a piece of paper, which turned out to be a letter from a disgruntled officer petitioning General Akyeampong for a promotion. Other papers retrieved had a similar content. We were tromping on the historical record of Ghana's military regimes that had ruled from 1972 to 1979 . At the end of our tour, we were welcomed by President Kufuor's spokesperson. As historians we expressed our concern about the country's archival record lingering in these damp dungeons. We learned that officials of the (P)NDC regime of J. J. Rawlings had relocated the files because of space problems. The current government would certainly look for a permanent solution to properly store the material. Ghanaian colleagues, veterans of the Castle tour, commented that they had received the same answer when raising the issue of the dungeon files the previous year. Thus, most likely, no action would happen." (Miescher, 2009)

Ghana actually set up a government ministry for record keeping and national archives, operating few miles north of the castle in the capital Accra. However, lack of administrative transparency, underfunding, mistrust of the potentially critical or even socially divisive power of history ${ }^{7}$, and the existence of more pressing problems than unhappy historians all render historical, and especially archival work, difficult. By highlighting my experience in Ghana I am not trying to point fingers - on the contrary Ghana has researchable records and an archival infrastructure, which is not universally the case in poor countries. Many of these problems are compounded when researching postcolonial business records (Klubock, 1998). Unfortunately, as the first fifty years of postcolonial history are becoming a historically researchable time period, the surviving archival record may come to be compared to the European Middle Ages in terms of their gaping silences. Considering the importance of this time period for the formation of states, identities and economic organization, these are very grave silences indeed.

As a result, much of postcolonial history relies on oral history interviewing, or the laborious negotiations of accessing private files held by individuals, families or community leaders. Some of the larger multinational subsidiaries have archival records, but again it can take a long time negotiating and gaining trust to be able to access them, even if agreement from headquarters has been provided. Yet certain organizations with many international links and a strong professional identity have built up substantial and remarkable collections of records. One of them is the public electricity utility in Ghana, the Volta River Authority (VRA) that Stephan Miescher (2009) described. Their archive in Tema, though hard to

\footnotetext{
${ }^{7}$ For Westerners coming from established nation-states, I think this point is hard to grasp. On the Annual conference of the Historical Society of Ghana 2006, the discussions around the issues of language or the history of sub-national minorities served as important reminders of the way history is used in identityformation - a point made most clearly by (McNeill, 1986) History can easily bent to support political agendas and is thus potentially dangerous: (Southgate, 1996), p. 132 [Kindle edition]
} 
physically access in an industrial estate, is well organized and well-kept. Once permission was granted from the director, there was no embargo on any types of files or date ranges, and the collections showed clear patterns in terms of distinct series and deposits from functional departments.

This description of different types of archives should highlight the first significant characteristic of working with historical records: serendipity. As historical research depends on remains or artifacts of the past, any research strategy has to be flexible in order to work with what is there, and what has been silenced. This is a key problem of historical research that determines its methodologies.

\subsection{The silence of the archives}

Archives can be silent for many different reasons, and the silences can be caused at different levels of the production and deposit process that culminates in an accessible archive. This can stretch from the suppression of certain kinds of information by archivists through access policies or weeding, decisions about what to deposit by business, as well as what kind of information organizations deem important to collect in the first place. It is really at this basic level that post-colonial thinkers have made important contributions to historical understanding, especially Edward Said (1991) and Gayatri Chakravorty Spivak's (1988) emphasis that silences may run deep in the fabric of society and its organizations.

Although it is not always possible to establish definitively at which stage of the process a gap occurred in the historical record, it can add a lot to careful historical analysis. This is why historians put great emphasis on source triangulation and frequently highlight the need to work with more than one archive, as this facilitates not only the "filling of gaps", but also the identification of bias and silences in sets of records. The following lists some of the major practices that lead to gaps and biases in the files, in the reverse order of the creation process:

- Access to information policies

- "Weeding" and later de-accessioning by archivists

- Organisational principles of archiving

- Selection of documents to archive

- Types of sources and information beyond their content

- Collection of information for immediate purposes

- Postcolonialism and silences in the creation of documents

The simplest and easiest to reconstruct silences are those that are the result of explicit policies, such as embargoes or creating confidential categories that are off-limits for researchers. A good example for such a practice is the World Bank's new access to information policy. Files are only released after having been checked for certain document types, which are removed on grounds of different types of confidentiality: personnel files such as salary or CVs, but also any information provided by third parties in confidence (The World Bank, 2010, pp. 3- 
7). All removed files are indicated in the folder with their titles and the reason for their exclusion. Although in some cases unfortunate, this gives researchers a relatively clear picture of the extent and the nature of the silence.

More problematic is the removal of documents by archivists preparing a deposit for the archive. Once a structure is established by which a catalogue is created that is unique to the deposit, archivists take decisions on which files are worth keeping. This process is known as "weeding", and helps archives to manage space. Many deposits do not consist of clearly managed records, rather they can be the equivalent of a filing cabinet full of material that once had some relevance to the organization it created, and their value can be quite transitory. On rare occasions one finds a folder full of dinner invitations, or photocopier maintenance reports. But the research areas that history considers relevant have changed significantly in previous decades. While once it was only the political decisions of great men that mattered, today's research is also interested in the everyday practices and shifting attitudes, and these theoretical concerns have led to the investigation of different types of records. ${ }^{8}$

There is another form of archivists' interventions, "de-accessioning", which means that parts of the collection are removed after they were catalogued. An unfortunate example of this has been the archive of the Bank of England, especially in the overseas department. Here many country collections were removed, see for example the entry for Iran (Suddaby, et al., 2010, p. 57). All reconstruction that is possible here is the realization that there may have been fascinatingly rich documents for many countries that have now been destroyed, so other archives need to be identified. Most historical research is based on more than one archive, precisely because this is a way to access duplicate records or multiple points of view.

Archives are organized on the basis of certain principles, like libraries. There are two key principles, the principles of pertinence and provenance. Pertinence was the main principle by which archives were organized in the nineteenth century, where files were arranged by the topics or issues they contained. This is now considered a way to destroy the context of origin of an archival collection, thus today archives are organized by the principle of provenance. In recent years, new cataloguing methods such as "macro-appraisal" (Cook, 2004) have extended the core idea of provenance in order to improve archivists' ability to identify "valuable" sources for the future.

Archives consistently managed by overarching principles allow the reconstruction of information flows and (re-)organization of departments in a business, potentially allowing a reconstruction of strategy over very long time periods. Yet large corporate archives that cover extremely long time periods can be tricky for archivists to catalogue - the United Africa Company being one example. The company's archive contained predecessor companies, merged companies, companies that had legal status but no functional operations, branches that became subsidiaries, and changes to functional departments at

\footnotetext{
${ }^{8}$ This has also affected the practices of archivists, see for example (Green \& Kinsey, 1999) There are also resources available for archivists to reconsider the cataloguing of their material in the light of new approaches to research: (Collections Link, 2011)
} 
headquarter level. Organising files in an organisational structure that itself was not documented and that was constantly in flux has made this a difficult archive to catalogue, and it is worthwhile when doing research to gain clarity not just about the structure, but in some cases, where possible, also about the work of the cataloguing archivist. On the other end of the spectrum is the World Bank archive that provides organisational diagrams over time that tracks internal reorganisations - but this is only possible with continuous archival and records management service.

Then there is the issue of files deposited by companies into libraries, especially if this occurred at a time when the business was still operational. Here the question arises of the intention behind the deposit. This is quite obvious behind an archival deposit to Oxford University's Rhodes House by John Holt \& Co. The company is still operational, and some of their historical files are also held by the Liverpool Records Office. Yet those with relevance to the decolonization period were deposited in the 1970s and generally show very progressive political attitudes on the part of the firm's management. ${ }^{9}$ This is one of the cases where a certain amount of skepticism is warranted, and files should be triangulated with material from other organizations.

It is generally less likely that certain incriminating files were systematically destroyed in sizeable business archives that accumulated as the result of organizational record keeping without any immediate archiving. This is simply because a lot of information was circulated through departments on paper as minutes, correspondence and short notes - it is unlikely that these could have been effectively removed later on, because, as a rule, too many copies were circulated through different departments. In smaller, more thematic collections this is a different issue, hence the question of whether incriminating files were strategically removed before depositing is relevant in this context.

Somewhat different is the case with highly political, confidential information, especially on clandestine activities. If business archives are based on the collection by leading corporate officials, such as the Kaiser archives at the Bancroft Library at Berkeley, it is possible that they were extremely careful on what they put on paper and whether it was filed. With regard to this collection, for example, the question arises whether Edgar Kaiser and his close associates knew of the CIA's involvement in the overthrow of the president of Ghana, Kwame Nkrumah. There are contemporary observations that they were informed in advance of a planned coup. The files themselves show no such evidence. There is a reference to having been approached by the CIA to collaborate, which was rejected. The local business community was well aware of which US American firm was just a CIA front. Yet the files show a strategic reorientation of the company with regard to its political activities over a certain time period without any reference to what this reassessment has been based on. Hence the absence of any intelligence information in the files cannot be read as definitive evidence that the firm had no knowledge of CIA activities (Decker, 2011).

\footnotetext{
${ }^{9}$ The 1970 s were a time period when business legitimacy was challenged globally and when the firm faced expropriation in West Africa. (Decker, 2008)
} 
When archival collections show little evidence of any such gaps, as is often the case for public and national archives, as well as very complete organizational archives that have been more or less continuously managed, they provide an insight into biases and silences of a different kind. At this level archives speak very loudly of the cognitive frameworks espoused in organizations. An example of a historical analysis based on such an archival reading is Ronald Robinson and John Gallagher's (1961) Africa and the Victorians, who argued that British colonialism showed an "official mind". Business historians have not always used sources sufficiently in this regard, and approaches from organization studies may provide useful complements. The next section will deal in greater deal with this issue.

Archives can also be used to recreate the conditions of the collection of knowledge itself. How do organizations seek to create a structured body of knowledge over an alien "other" has been researched for example by van den Bersselaar (2004), who reconstructed the practices of censuses and drawing of ethnic maps by colonial officials in Nigeria. This is a good example of the often fundamental importance that the work of Edward Said and Gayatri Chakravorty Spivak have had on the practice of historians working in non-Western areas. The very creation of knowledge and historical records show evidence of "othering" and selective "silencing" that can be reconstructed from the practices of administration and rule, for example from court records that show "malfeasance" in the widest sense. In these sources, information tends to be thin, and there is little if anything on the motivations of "others". Similar work on business archives that highlights cultural or gender issues has now become more common (Johnson, 2007; Murillo, 2010; Robertson, 2010; van den Bersselaar, 2007).

\subsection{When archives do speak}

Despite the many silences that research in archives tends to encounter, archives, especially larger ones, usually "speak" in recognizable voices - something that nearly all practicing historians experience. What for the anthropologists is their first year of fieldwork somewhere far away, for the historian is their first archive. This rite of passage involves facing an unknown amount of data which is usually too little, too much or both at the same time (but for different time periods or themes), which immediately requires the setting of a boundary that delineates what to look at in the first instance, which may require redefinition in the light of the amount and quality of material available.

As one comes to grips with the catalogue and begins ordering folders of unknown sizes and usefulness from terse descriptions by archivists, historical records begin to speak. I can still recall my enthusiasm after my first week in the archive, which was as if having entered a story that was told in a disjointed fashion, and needed to be pieced together. Today I see this as the result of the archive itself being a record of the stories and the sense-making of past actors. Organizational archives, especially within certain time periods, have an overarching "tenor", created by the interaction of people within the social context of the organization. Hence Evans (1999), amongst others, has resisted claims of the complete narrativity of historical writing, as there are indeed very stringent 
limitations on the kind of claims one can make on the basis of the historical evidence - not just on the basis of what it says or remains silent on, but also in the sense of common themes, attitudes, biases and argumentations, as well as breaks from the norm and how they are dealt with. This provides a rich description context (Geertz, 1973) that limits interpretation.

This is why historians have highlighted the importance of being close to the sources. Yet this does not mean that the historian is nothing but a ghost-writer who helps the archive speak. Not only is there a danger, in EH Carr's words, that historians will know more and more about less and less (Carr, 1961), but there is also an inherent need of an analytical distance to historical evidence embodied in source criticism.

Source criticism focuses on the difference between types of sources, mostly on the basis of time. A primary source is the document that is closest in time to the event it refers to. Yet obviously the analysis of those texts would have to be different. Hence beyond the first principle of the time of creation relative to the event, the second principle is the degree of future orientation of the source: was it written for posterity? A third principle in business history is whether the files were internal or intended for public release. Hence truth claims in memoirs are treated differently from those in correspondences or reports, as the former have been created with the intention of interpreting historical events.

As a result, although this depends somewhat on the research question, sources that are close in time, internal and written with only immediate uses in mind are deemed more valuable. Those are really the "most primary" of the primary sources. And this is where postmodern and post-colonial criticisms of historical practice have been most important. It is often evident that historians' treatment of these kinds of sources have been at times uncritical.

While Spivak's (1988) analysis of sati seems to follow postmodern practice to see all kinds of text as equal (a claim that has not found acceptance by the majority of historians), in her effort to reconstruct and represent the subaltern perspective she drills deeper into historical records until she analyses the Sanskrit texts and their questionable interpretations that gave rise to an alternative construction of sati. Although not strictly speaking a historical analysis, as she does not provide reference to sources that allow others to replicate her analysis, this engages source criticism in a historical sense, yet goes significantly further in challenging the purported bias of the primary source. Postcolonialism's focus on the silence of the subaltern has had profound importance for non-Western history precisely because of the limitation of the archives, requiring the use of more tangential, non-traditional sources such as images or oral history (Green \& Kinsey, 1999; Vansina, 1985).

And this is why historians cannot become the ghost-writers of the archive without writing poor history. The first archive that spoke to me was unmistakably racist, sexist, elitist, Anglo-Saxon and of a bygone era where one referred one's peers and employees as "chaps" and said things like "cheerio" without any irony. Yet despite this significant mental distance, it takes effort to not simplistically accept the sense-making that occurs within historical records. The archives I researched allowed me to follow the point of view of those who discriminate against employees on the basis of their race and gender. This was 
justified in terms of an internal logic of maintaining standards, organisational trust, as well as interpersonal intelligibility and predictability (Decker, 2010). These attitudes permeated the records, and it was not always easy to find dissonance within the archive, as these beliefs influenced the practices that created the records in the first place. In these situations theoretical and methodological concerns play an important role in historical analysis. In my case, a sociological study by Michael Burawoy on advancement and empowerment in the Zambian copper mines provided important concepts against which to test my historical sources, but even here alternative explanations following an internal logic existed in the files (Decker, 2010).

Due the problematic nature of post-colonial record-keeping, which limits the ability of researchers to triangulate different types of archives in order to minimize inherent source bias (most notably the absence of many African archives, both public and corporate) methodological and theoretical concerns loom larger. At a methodological level, oral history and the interpretation of visual or physical artifacts have greater importance, as well as the influence of postcolonial critiques. Yet it is not just the silence of archives that creates research problem, but also the overabundance of records for certain aspects.

\subsection{Can you sample an archive?}

Although historians, for obvious reasons, prefer too many records to too few, this creates its own problems. I have worked in several archives where the boundaries set in terms of time and topic brought up too many records to be reasonably researched, but where the comparability of different archives or the nature of the research question did not allow narrowing the boundaries. Here William McNeill's comment on "the historian exhausting the records before they exhaust the historian" is a problem of some methodological concern (McNeill, 1986). Unfortunately, historians like McNeill, who highlight the importance of generalization from historical specifics, give no practical advice whatsoever (similar to Evans' advice to follow "the usual rules of evidence").

I suspect most historians follow the unwritten rules of their discipline and muddle through with a variety of individual strategies. I was somewhat lucky that this was a problem that already occurred during my doctoral research, and that this was a discussion I could have with my doctoral supervisors. On occasion, historians detail their sampling strategies, especially when they create semi-quantitative databases (Rutterford, Maltby, Green, \& Owens, 2009). Thus I can only assume that there are significantly more sampling techniques in existence than I will detail here from my own practice.

The first archive where I encountered the necessity for sampling was the Ashanti Goldfields Corporation (AGC) archive, which is kept in the Guildhall Library, London. This consisted primarily of one series of outbound correspondence from the London headquarters to the mine in Obuasi, Ghana, and a complementary set of inbound letters. In the early years of my research period, each set consisted of one large ledger per year, per series. This soon turned to two ledgers per year, then briefly three, followed by four, eventually culminating in six ledgers, only slightly thinner than the original one-year tomes. My research time period was 
just shy of thirty years. For most years a hand-written index existed, which was often unreliable and rarely indexed what I was interested in, and which I thus quietly abandoned at some point. The AGC was one of five companies I researched for my $\mathrm{PhD}$ thesis. ${ }^{10}$

It is standard practice in business history to begin working on the files originating from the highest point in the hierarchy, i.e. the board papers, and percolate down. When researching multinational subsidiaries, I have not always found this practice useful. At Barclays Bank DCO, the board records were terse and uninformative. Yet visiting reports to overseas branches, undertaken with increasing frequency, minutes of meetings and correspondence provided important insights into subsidiary management. At Unilever, however, the committee structure and a somewhat bureaucratic style of record keeping meant that central, high level files showed detailed discussions of subsidiary issues. For the AGC, board records did not exist. Yet the size of headquarter-subsidiary correspondence suggests that particularly for a freestanding company, management occurred at the international nexus, not at the top level where the company communicated with a multiplicity of small investors via the stock exchange (Maltby \& Tsamenyi, 2010). ${ }^{11}$

Clearly this raises issues for comparative archival studies, where social science techniques of comparing the same types of records across institutions simply cannot be applied. Having seen a number of large and small organizational archives, there is little mimetic or regulatory isomorphism in evidence in terms of their internal practices. This means that each organizational archive needs to be understood on its own terms before it can be usefully compared. Not just the archivist, but also the historian has to consider the principle of provenience when evaluating documents - and in large archives this is much more difficult to apply than in smaller ones.

How to proceed when faced with too much material? Firstly I looked at similar volumes in both series, and determined that it was the inbound correspondence that contained richer documentation of the issues that were of relevance to my research question. This way I eliminated half the material. Unfortunately, the remaining files were still too many to allow in depth research, especially as they contained files that pointed towards emerging issues that were relevant but that I could not have predicted. These are the kinds of time-bound analytical issues that are crucial to historical analysis. I suggested to sample volumes at regular intervals (commonly done in economic history time series), something that my supervisors rejected as an approach.

They suggested instead sampling by historical event or periodisation, meaning to focus on those years where it was known that political events (change of government, elections), economic events (strikes, foreign exchange crises) or legislation directly affecting business (expropriation, taxation or regulatory

10 One of my colleagues wrote her PhD on the history of the AGC - spanning over 100 years, for which she searched for files in and beyond the Guildhall archives: (Afrifa Taylor, 2006)

${ }^{11}$ I am not aware that any research on freestanding companies has focused on their organisational practices. 
changes) occurred.12 In African history, this unfortunately leaves rather a lot of dates, so of those only the most important ones could be covered, which is invariably subjective, and even so would in no way guarantee that the kind of files I was looking for would be with this crisis and not the previous one (historical contemporaries obviously did not always know which one would be the 'biggest' crisis, nor are organizational practices fully determined by environmental events). Archival research always depends on serendipity, and sampling on the basis of chronology and periodization is an attempt to maximise opportunity as well as coverage while minimizing workload.

Having recently done archival research at the World Bank (which keeps its records in an abandoned mine outside Washington, DC, for space reasons), the problem of limited research time, abundance of material, and unclear labeling of files (at least for my purposes) reoccurred. Here there were a number of different file series, some of which could be excluded, but useful series invariably contained too many folders to be fully researched. My research strategy was based on focusing on the first and last two folders of a series, so that in case there were major changes apparent, the remaining folders could be used to pinpoint those changes in time. Otherwise folders in the middle of the series were picked on the basis of significant dates, which in some cases worked out well, but on occasion yielded no results.

Overall my sampling logic was that of a puzzle, where a series presents a picture, of which first the boundary and then significant objects within the picture needed to be established sufficiently so that the remaining blanks were not so major that the overall picture could not be reconstructed to a significant degree. ${ }^{13}$ Some archival silences are not inherent in the records, but the result of a research process where sources can only speak selectively - either as a result of source analysis or of different sampling techniques.

\section{Conclusion}

While the concept of silences, both of the subaltern and the historical record, has been powerfully highlighted by postcolonial scholars, many interpretative methodologies from the social sciences are not suited to understand the different layers of silences that are relevant to archival research. This includes the techniques used by historians when collecting data, and the role of archivists as mediators. While some degree of selection is usually necessary to deal with historical sources, the criticism of historical narratives has unduly focused on this level, ignoring the fact that this is just one layer of historical methodologies. Yet ironically, historians may have even more effectively silenced themselves

\footnotetext{
${ }^{12}$ Creating chronologies as the first step of analysis has also been suggested by Mills and Helm Mills (they refer to it as the identification of junctures), but I would argue that they are already significant when data is collected. (Mills \& Helms Mills, 2011)

13 Obviously this puzzle analogy has its limits - I do not think that what I reconstruct is one hundred percent fixed in time and space, and only requires me to "find out" what the final image is.
} 
when it comes to their methodological knowledge than they could have ever silenced their archives.

The easiest way for historians to grasp what is required when trying to communicate with social scientists is, in my view, Gaddis' (2002) use of the image of the Centre Pompidou: a building that presents all its structural elements (ducts, pipes etc.) on the outside, rather than hiding it behind a façade. Sure, it is ugly, but it works. Describing basic research strategies, to a historian, sounds simply inane, and is further complicated by a lack of familiarity with the terminology and standard formats of the social sciences. Even more so, there is considerable resistance against having to explicate practice. At the Business History Conference in 2011, there were impassioned discussions against the suggestions from the panelists to add material on methodology to historical narratives when submitting to social science journals.

Personally I think this resistance is misplaced - quite simply because I am offended when I am told that what I am doing are "small n-studies" or anecdotal. I do not think that our critics have to go to archives themselves before we can tell them that the n's go on for miles in there! As the historian MacRae said: "Sociology is history with the hard work left out. History is sociology but the brains left out" ("Some Sociological Prospects", 1957, p. 302, cited in Kieser, 1994, p. 612). I think I can live with being told that we as historians are not overly theoretical but craft-based. But considering the thin and often questionable nature of data in social sciences (at least from a historian's perspective), much of which is not even identifiable or accessible to others, I really think that our data collection (and analysis) stands up in comparison with what social scientists do.

Working as a business historian of Africa, it is hard to overestimate the important contribution that postcolonialism has made to archival practice. Postcolonialism was essential to historians working on non-European history precisely because it supported a more sophisticated methodology for archival research. Archival ethnography especially allows us to extend historical methods through better contextualization.

However, postcolonialism also reminds us that all reconstruction, especially when presented to a lay audience of non-historians, invariably becomes representation. All selection of archival material for narrative, whether through sampling, causal analysis or exemplary selection, involves reconstruction, representation, and therefore silencing. We ought to be clear about this, and beginning to state our methodology is one way of achieving this. Because without historical representation, archival voices cannot speak meaningfully either. 


\section{References}

Afrifa Taylor, A. (2006). An Economic History of the Ashanti Goldfields Corporation, 1895-2004: Land, Labour, Capital and Enterprise. PhD, University of London, London.

Amatori, F., \& Jones, G. (2003). Introduction. In F. Amatori \& G. Jones (Eds.), Business History around the World (pp. 1-7). Cambridge: Cambridge University Press.

Austin, G. (2012). History, Archives and Development Policy in Africa. Paper presented at the Using History to Inform Development Policy: The Role of Archives, Washington DC.

Birkinshaw, J. (2004). Publishing Qualitative Research in International Business. In R. Marschan-Piekkari \& C. Welch (Eds.), Handbook of Qualitative Research Methods for International Business (pp. 570-584). Cheltenham, UK, and Northampton, MA: Edward Elgar.

Breckenridge, K. (2012). From Parliamentary Accountability to Records Management: The Decline of Archival Authority in modern South Africa. Paper presented at the Using History to Inform Development Policy: The Role of Archives, Washington DC.

Business Archives Council. (2011). Meet the Archivist Retrieved 7 December, 2011, from http://www.businessarchivescouncil.org.uk/activitiesobjectives/meetarchivists/

Carr, E. H. (1961). What is History? (With a new introduction by Richard J Evans ed.). Basingstoke: Palgrave Macmillan.

Clark, P., \& Rowlinson, M. (2004). The treatment of history in organisation studies: towards an 'historic turn'. Business History, 46(3), 331-352.

Cohn, B. S., \& Dirks, N. B. (1988). Beyond the Fringe: The Nation State, Colonialism and the Technologies of Power. Journal of Historical Sociology, 1(2), 224229.

Coleman, D. (1987). The Uses and Abuses of Business History. [Article]. Business History, 29(2), 141-156.

Collections Link. (2011). Revisiting Collections Retrieved 4 December, from http://www.collectionslink.org.uk/programmes/revisiting-collections

Cook, T. (2004). Macro-appraisal and functional analysis: documenting governance rather than government. Journal of the Society of Archivists, 25(1).

Cooper, F., \& Packard, R. M. (Eds.). (1997). International development and the social sciences: essays on the history and politics of knowledge. Berkeley, CA, London: University of California Press.

Decker, S. (2008). Building up goodwill: British business, development and economic nationalism in Ghana and Nigeria, 1945-1977. Enterprise and Society, 9(4), 602-613.

Decker, S. (2010). Postcolonial Transitions in Africa: Decolonization in West Africa and present day South Africa. Journal of Management Studies, 47(5), 791813. doi: 10.1111/j.1467-6486.2010.00924.x

Decker, S. (2011). Corporate Political Activity in Less Developed Countries: The Volta River Project in Ghana, 1959-1966. Business History, 53(7).

Delahaye, A., Booth, C., Clark, P., Procter, S., \& Rowlinson, M. (2009). The genre of corporate history. [Research paper]. Journal of Organizational Change 
Management, 22(1), 27 - 48. doi: DOI:

(Permanent URL)

Dirks, N. B. (2002). Annals of the Archive: Ethnographic Notes on the Sources of History. In B. K. Axel (Ed.), From the Margins: Historical Anthropologu and its Futures (pp. 47-63). Durham: Duke University Press.

Down, S. (2001a). Knowledge Sharing Review the Use of History in Business and Management, and Some Implications for Management Learning. Management Learning, 32(3), 393-410. doi: 10.1177/1350507601323006

Down, S. (2001b). Knowledge Sharing Review: The Use of History in Business and Maangement, and Some Implications for Management Learning. Management Learning, 32(3), 393-415. doi: DOI: 10.1177/1350507601323006

Duara, P. (1998). Why is History Antitheoretical? Modern China, 24(2), 105-120.

Ellis, S. (2002). Writing histories of contemporary Africa. Journal of African History, 43(1), 1-26.

Eloranta, J., Ojala, J., \& Valtonen, H. (2008). Are Business Historians Quantitatively Illiterate? Paper presented at the European Business History Association, Bergen, Norway.

Eloranta, J., Valtonen, H., \& Ojala, J. (2010). Methods, Topics, and Trends in Recent Business History Scholarship, ABH Newsletter.

Evans, R. (1999). In Defense of History. New York: W. W. Norton \& Co.

Gaddis, J. L. (2002). The landscape of history: how historians map the past. Oxford: Oxford University Press.

Geertz, C. (1973). The interpretation of cultures: selected essays by Clifford Geertz $(1 \mathrm{st}$

2nd Hutchinson 1975 ed.). New York: Basic Books.

Godelier, E. (2009a). Comments on Comments, or the Richness of Dialogue. Enterprise and Society, 10(4).

Godelier, E. (2009b). History, a Useful "Science" for Management? From Polemics to Controversies. Enterprise and Society, 110(3).

Green, E., \& Kinsey, S. (1999, June). Completing the picture: records of the national staff of international banks since the mid-19th century. Paper presented at the European Banking Overseas 19th - 20th Century. Proceedings of the conference hosted by ABN-AMRO Bank N.V., Amsterdam.

Iggers, G. G. (2009). A search for a Post-Postmodern theory of history. [Book Review]. History and Theory, 48, 122-128.

Johnson, V. (2007). British multinationals, culture and empire in the early twentieth century. PhD, King's College, London.

Jones, G., \& Khanna, T. (2006). Bringing history (back) into international business. Journal of International Business Studies, 37(4), 453-468.

Kieser, A. (1994). Why Organization Theory Needs Historical Analyses-And How This Should Be Performed. Organization Science, 5(4), 608-620.

Klubock, T. M. (1998). Contested communities: class, gender, and politics in Chile's El Teniente copper mine, 1904-1948. Durham, NC: Duke University Press.

Kobrak, C. (2009). The Use and Abuse of History as a Management Tool: Comments on Eric Godelier's View of the French Connection. Enterprise and Society, $10(4)$.

Kobrak, C., \& Schneider, A. (2011). Varieties of business history: Subject and methods for the twenty-first century. Business History, 53(3), 401-424. doi: 10.1080/00076791.2011.565515 
Lorenz, C. (2011). History and Theory. In A. Schneider \& D. Woolf (Eds.), The Oxford History of Historical Writing (Vol. 5: Historical Writing Since 1945, pp. 13-35). Oxford: Oxford University Press.

Maltby, J., \& Tsamenyi, M. (2010). Narrative accounting disclosure: Its role in the gold mining industry on the Gold Coast 1900-1949. [doi: DOI: 10.1016/j.cpa.2010.03.001]. Critical Perspectives on Accounting, 21(5), 390401.

McNeill, W. H. (1986). Mythistory, or Truth, Myth, History, and Historians. The American Historical Review, 91(1), 1-10.

Mees, B., \& Walker, M. (2009). The Use and Abuse of Business History. Paper presented at the AAHANZBS, New Zealand.

Miescher, S. (2009). The Volta River Authority and the Production of Knowledge in Ghana. Paper presented at the Production of Knowledge in Africa, University of Michigan, Ann Arbor.

Mills, A. J., \& Helms Mills, J. (2011). Digging Archaeology: Postpositivist Theory and Archival Research in Case Study Development. In R. Piekkari \& C. Welch (Eds.), Rethinking the Case Study in International Business and Management Research (pp. 342-360). London: Edward Elgar.

Murillo, B. (2010). "The Devil We Know": Gold Coast Consumers, Local Employees, and the United Africa Company,

1940-1940. Enterprise and Society.

Newton, L., \& Carnevali, F. Researching Consumer Durables in the Nineteenth Century: The Case of the Piano. Business Archives: Sources and History

Newton, L., \& Carnevali, F. (2010). Researching Consumer Durables in the Nineteenth Century: The Case of the Piano. Business Archives: Sources and History 101(November), 17-29.

Piekkari, R., \& Welch, C. (Eds.). (2011). Rethinking the Case Study in International Business and Management Research. Cheltenham: Edward Elgar Publishing.

Popp, A. (2009). History, a Useful" Science" for Management? A Response. Enterprise and Society, 10(4).

Robertson, E. (2010). Chocolate, Women and Empire: A Social and Cultural History. Manchester: Manchester University Press.

Robinson, R., \& Gallagher, J. (1961). Africa and the Victorians: The Official Mind of Imperialism. London: Macmillan.

Rowlinson, M., \& Delahaye, A. (2009). Le tournant culturel en histoire des entreprises [The Cultural Turn in Business History]. Entreprise et histoire, 55.

Rowlinson, M., Stager Jacques, R., \& Booth, C. (2009). Critical Management and Organizational History. In M. Alvesson, H. Willmott \& T. Bridgman (Eds.), Handbook of Critical Management Studies (pp. 286-303). Oxford: Oxford University Press.

Rutterford, J., Maltby, J., Green, D. R., \& Owens, A. (2009). Researching shareholding and investment in England and Wales: Approaches, sources and methods. Accounting History, 14, 269-292. doi: doi: $10.1177 / 1032373209335292$

Said, E. W. (1991). Orientalism: Western Conceptions of the Orient. London i.a.: Penguin.

Southgate, B. (1996). History, What and Why?: Ancient, Modern and Postmodern Perspectives. London, UK: Routledge. 
Spivak, G. C. (1988). Can the Subaltern Speak? In C. Nelson \& L. Grossberg (Eds.), Marxism and the Interpretation of Culture (pp. 271-313). Urbana, IL: University of Illinois Press.

Stoler, A. L. (2009). Along the Archival Grain: Epistemic Anxieties and Colonial Common Sense. Princeton: Princeton University Press.

Suddaby, R., Foster, W. M., \& Trank, C. Q. (2010). Rhetorical History as a Source of Competitive Advantage. Advances in Strategic Management, 27, 147-173. doi: doi:10.1108/S0742-3322(2010)0000027009

The National Archives (UK). (2011). Access to Archives Retrieved 4 December 2011, from http://www.nationalarchives.gov.uk/a2a/

The World Bank. (2010). The World Bank Policy on Access to Information (pp. 20). Washington DC: World Bank.

Tiffany, P. (2009). Does History Matter in Business? Enterprise and Society, 10(4).

Trouillot, M.-R. (1995). Silencing the Past: Power and the Production of History. Boston: Beacon Press.

University of Reading. (2011). New Special Collections acquisitions Retrieved 4 December 2011, from http://www.reading.ac.uk/specialcollections/news/exhibitions/sc-exhibition-newscacquisitions.aspx

van den Bersselaar, D. (2004). Establishing the facts: P.A. Talbot and the 1921 census of Nigeria. History in Africa, 31, 69-102.

van den Bersselaar, D. (2007). The King of Drinks: Schnapps Gin from Modernity to Tradition (Vol. 18). Leiden and Boston MA: Brill.

Vansina, J. (1985). Oral Tradition as History. Madison, Wisconsin: University of Wisconsin Press.

Westwood, R. (2004). Towards a Postcolonial Research Paradigm in International Business and Comparative Management. In R. Marschan-Piekkari \& C. Welch (Eds.), Handbook of Qualitative Research Methods for International Business (pp. 56-83). Cheltenham, UK, and Northampton, MA: Edward Elgar.

Wilson, C. (1954). The History of Unilever: A study in economic growth and social change (Vol. 1). London: Unilever.

Wilson, J., \& Toms, S. (2008). Fifty years of Business History. Business History, $50(2), 125-126$.

Zammito, J. H. (1993). Are We Being Theoretical Yet? The New Historicism, the New Philosophy of History, and "Practicing Historians". [Book review]. The Journal of Modern History, 65(4), 783-814. 